\title{
Duration of spermatogenesis in the vole (Microtus agrestis) and bank vole (Clethrionomys glareolus)
}

\author{
C. Anne Grocock* and J. R. Clarke \\ Department of Agricultural Science, University of Oxford, U.K.
}

The duration of the cycle of the seminiferous epithelium is a fundamental parameter of spermatogenesis in mammals (Heller \& Clermont, 1964). Its measurement in the field vole (Microtus agrestis) could clarify the way in which seasonal changes in spermatogenesis in this species (Clarke \& Forsyth, 1964 ) are brought about. Furthermore, in our laboratory colonies puberty in $M$. agrestis occurs at about 6 weeks of age, whereas in the bank vole (Clethrionomys glareolus) it is 5-6 weeks later (Greig, 1968). The duration of the seminiferous epithelial cycle has therefore also been estimated in $C$. glareolus to determine whether this dissimilarity is associated with a difference in the duration of the cycle of the seminiferous epithelium.

As in other species (Roosen-Runge, 1962), spermatogenesis in M. agrestis (Grocock, 1972; Grocock \& Clarke, 1975) and C. glareolus (Grocock, 1972) can be divided into 8 stages whose frequencies may be determined. The duration of a cycle of the seminiferous epithelium can be established by combining these data with observations on the progression through the epithelium of germ cells labelled with $\left[{ }^{3} \mathbf{H}\right]$ thymidine (Clermont \& Trott, 1969). The complete process of spermatogenesis, from the first division of spermatogonia in stage 5 to the final release of spermatozoa in stage 8 , comprises approximately $4 \cdot 6$ cycles (Grocock, 1972).

\section{Microtus}

Sexually mature males were used and, except where otherwise stated, were kept in a photoperiod of $16 \mathrm{hr}$ light/day. Each was injected s.c. with $25 \mu \mathrm{Ci}\left[{ }^{3} \mathrm{H}\right]$ thymidine (sp. act. $2 \mathrm{Ci} / \mathrm{mmol}$; Radiochemical Centre, Amersham) in $0.1 \mathrm{ml}$ distilled water. Wild $M$. agrestis were trapped in Wytham Wood, Oxford, in July 1971, brought into the laboratory and injected on the next day. They were killed in pairs at $4 \mathrm{hr}, 4$ days or 7 days after injection. The remaining animals, from the Department of Agricultural Science colony, were killed in groups of 6 at $4 \mathrm{hr}, 6$ days $20 \mathrm{hr}, 8$ days $22 \mathrm{hr}$ or 18 days after injection. Twenty-four $M$. agrestis were matched in pairs for body weight, age and sexual development. Each animal of a pair was allocated at random to one of two treatments, 'summer' light (16L:8D) and 'winter' light (6L:18D) (Clarke \& Kennedy, 1967). After 7 weeks in these light regimens all animals were injected with $\left[{ }^{3} \mathrm{H}\right]$ thymidine and killed 7 days later. Testes were fixed in absolute alcohol : glacial acetic acid $(3: 1 \mathrm{v} / \mathrm{v})$ for $24 \mathrm{hr}$ and embedded in paraffin wax. Sections $(5 \mu \mathrm{m})$ were mounted on subbed slides and dipped in Ilford L4 nuclear research emulsion (Rogers, 1967). Slides were placed in black, light-proof, boxes for $3-5$ weeks at $5^{\circ} \mathrm{C}$, and then developed. They were finally stained with Harris's haematoxylin. Within each testis 50 tubules were classified into the 8 stages of spermatogenesis at each of two (or with wild animals, three) locations at least $300 \mu \mathrm{m}$ apart. This gave totals of 200 or 300 tubules per animal. The most advanced cells labelled with [ $\left.{ }^{3} \mathrm{H}\right]$ thymidine were recorded for these tubules, so that by collating data for the different groups, the progression in the seminiferous epithelial cycle of the leading front of labelled cells could be established.

The frequencies of the stages for $M$. agrestis were similar to those already reported (Grocock \& Clarke, 1975). In the laboratory stock, cycle length was calculated to be $7 \cdot 9 \pm 0 \cdot 3$ days and the duration of the complete process, from the first division of spermatogonia to final release of spermatozoa into the lumen was $36 \cdot 6 \pm 1 \cdot 2$ days $(\mathrm{N}=24)$. Cycle length for wild animals was $7 \cdot 8 \pm 0 \cdot 3$ days,

\footnotetext{
* Present address: Department of Human Anatomy, University of Oxford, U.K.
} 
giving a total duration of spermatogenesis of $36 \cdot 3 \pm 1 \cdot 3$ days $(N=6)$. Amongst the animals subjected to different photoperiods, one 'summer' light male died, and 3 'summer' and 2 'winter' light animals were excluded from the analysis since they possessed inactive testes in which stages could not be recognized. In the remaining 18 voles, primary spermatocytes in stage 8 were the most advanced labelled cells. The number of tubules with such labelled spermatocytes, expressed as a \% of the total number of tubules at that stage, was $75.3 \pm 1.8$ for $16 \mathrm{~L}: 8 \mathrm{D}(\mathrm{N}=8)$ and $67.2 \pm 3.7$ for $6 \mathrm{~L}: 18 \mathrm{D}$ $(N=10)$. The difference between these figures is not statistically significant and the rate of spermatogenesis appeared to be the same in the two groups. Testes were significantly heavier in animals from 16L : 8D than those from $6 \mathrm{~L}: 18 \mathrm{D}(380.9 \pm 36.9 \mathrm{mg} ; 248.5 \pm 20.8 \mathrm{mg} ; P<0.01)$, as found by Clarke \& Kennedy (1967).

\section{Clethrionomys}

Groups of 6 sexually mature animals from the Department colony, reared in $16 \mathrm{~L}: 8 \mathrm{D}$, were killed $4 \mathrm{hr}$ and 7,10 and 14 days after s.c. injection of [ $\left.{ }^{3} \mathrm{H}\right]$ thymidine. Its specific activity and dosage, and the treatment of the testes, was as described for Microtus. The frequencies of the stages of the seminiferous epithelial cycle are shown in Table 1 . The cycle length was $6 \cdot 7 \pm 0 \cdot 2$ days, and the total duration of spermatogenesis $31.0 \pm 0.7$ days, both significantly shorter than in $M$. agrestis $(P<0.002)$.

Table 1. The percentage frequencies (mean \pm S.E.M.) of the stages of spermatogenesis in 1200 cross sections of seminiferous tubules of 6 sexually mature bank voles (Clethrionomys glareolus) reared in 16L:8D

\begin{tabular}{|c|c|c|c|c|c|c|c|c|}
\hline $\begin{array}{l}\text { Stage of } \\
\text { spermatogenesis }\end{array}$ & 1 & 2 & 3 & 4 & 5 & 6 & 7 & 8 \\
\hline$\%$ Frequency & $8 \cdot 6 \pm 1 \cdot 3$ & $10 \cdot 1 \pm 1 \cdot 5$ & $7 \cdot 5 \pm 0 \cdot 6$ & $8 \cdot 8 \pm 0.4$ & $10 \cdot 6 \pm 0.7$ & $16 \cdot 6 \pm 0.5$ & $16 \cdot 2 \pm 0 \cdot 7$ & $21 \cdot 5 \pm 1 \cdot 3$ \\
\hline
\end{tabular}

\section{Discussion}

The duration of the cycle of the seminiferous epithelium seems to be characteristic of each mammalian species or strain, and varies at least from 6.7 days in C. glareolus to 16 days in man (Courot, Hochereau-de Reviers \& Ortavant, 1970). Although there has been some selection for high fertility within the colony of $M$. agrestis, which had been genetically closed for 13 years, there was no difference in the duration of spermatogenesis between laboratory and wild $M$. agrestis. The cycle was, however, significantly shorter in C. glareolus indicating that the difference in age at puberty between these two species may be associated with later initiation of spermatogenesis in C. glareolus than in M. agrestis.

The exposure of $M$. agrestis to short photoperiod appears to lower circulating levels of gonadotrophins and testicular hormones (Clarke \& Kennedy, 1967; Worth, Charlton \& MacKinnon, 1973), and alters germ cell survival (Grocock \& Clarke, 1975), but does not alter the duration of spermatogenesis (present study). The seasonal change in fertility of wild male $M$. agrestis is therefore probably caused by alteration in germ cell survival rather than change in the rate of spermatogenesis. Yet for the rat there is disagreement about whether the duration of spermatogenesis can change with alteration in the level of gonadotrophins and testosterone. Desclin \& Ortavant (1963) and Clermont \& Harvey (1965) treated hypophysectomized rats with gonadotrophins or with testosterone propionate, and suggested that if spermatogenesis occurs at all it proceeds at a constant rate. Boccabella (1967), however, presented evidence showing that spermatogenesis is slower in hypophysectomized rats treated with testosterone propionate than in normal animals.

We thank Mrs Judith Baker for expert technical assistance, the Smith Kline \& French Foundation for a grant to J. R. C. and the Ministry of Agriculture, Fisheries and Food for a postgraduate studentship (C.A.G.). 


\section{References}

Boccabella, A.V. (1967) In discussion following K.B. Eik-Nes: Factors controlling the secretion of testicular steroids in the anaesthetized dog. J. Reprod. Fert., Suppl. 2, 139-141.

Clarke, J.R. \& Forsyth, I.A. (1964) Seasonal changes in the gonads and accessory reproductive organs of the vole (Microtus agrestis). Gen. \& compar. Endocr.4, 233-242.

Clarke, J.R. \& Kennedy, J.P. (1967) Effect of light and temperature upon gonad activity in the vole (Microtus agrestis). Gen. \& compar. Endocr. 8, 474-488.

Clermont, Y. \& Harvey, S.C. (1965) Duration of the cycle of the seminiferous epithelium of normal, hypophysectomized and hypophysectomized-hormone treated albino rats. Endocrinology 76, 8089.

Clermont, Y. \& Trott, M. (1969) Duration of the cycle of the seminiferous epithelium in the mouse and hamster determined by means of ${ }^{3} \mathrm{H}$-thymidine and radioautography. Fert. Steril. 20, 805-817.

Courot, M., Hochereau-de Reviers, M.-T. \& OrtaVANT, R. (1970) Spermatogenesis. In The Testis, Vol. 1, pp. 339-432. Eds A. D. Johnson, W. R. Gomes \& N. L. VanDemark. Academic Press, New York and London.

Desclin, J. \& Ortavant, R. (1963) Influence des hor- mones gonadotropes sur la durée des processus spermatogénétiques chez le rat. Annls Biol. anim. Biochim. Biophys. 3, 329-342.

GREIG, F. (1968) Breeding and non-breeding seasons in the bank vole, Clethrionomys glareolus, with special reference to changes in the adenohypophysis. D. Phil. thesis, Oxford University.

Grocock, C.A. (1972) The influence of some environmental factors on the testis of the vole, with particular reference to spermatogenesis. D. Phil. thesis, Oxford University.

GROCOCK, C.A. \& ClARKe, J.R. (1975) Spermatogenesis in mature and regressed testes of the vole (Microtus agrestis). J. Reprod. Fert. 43, 461-470.

Heller, C.G. \& Clermont, Y. (1964) Kinetics of the germinal epithelium in man. Recent Prog. Horm. Res. 20, 545-575.

ROGERs, A.W. (1967) Techniques of Autoradiography. Elsevier, Amsterdam.

RoOSEN-RUNGe, E.C. (1962) The process of spermatogenesis in mammals. Biol. Rev. 37, 343-377.

Worth, R.W., Charlton, H.M. \& Mackinnon, P.C.B. (1973) Field and laboratory studies on the control of luteinizing hormone secretion and gonadal activity in the vole, Microtus agrestis. J. Reprod. Fert., Suppl. 19, 89-99.

Received 20 October 1975 